\title{
The language of the glosses in the Bornu quranic manuscripts*
}

\author{
DMITRY BONDAREV \\ School of Oriental and African Studies
}

\section{Introduction}

The Bornu ${ }^{1}$ manuscripts discussed in the present article were first described by A. D. H. Bivar in his publication of 1960 'A dated Kuran from Bornu' (Bivar 1960). The author gave a short but very informative account of four early quranic manuscripts with interlinear vernacular glosses in Arabic/Ajamic script, which he examined during his travels to northern Nigeria in 1958-59. Among the most remarkable findings of Bivar's investigation was the discovery of a date in one of the Qurans, and the identification of the vernacular language. Apart from the vernacular glosses, the dated manuscript, which was in the possession of Imam Ibrahim, Imam Juma Maiduguri (the head of the Muslim community of Maiduguri), carried an abridged Arabic commentary, the jamī ahkām al-qur'ān of al-Qurțubī, and a colophon with the date of completion of this commentary-1 Jumadi II, 1080 AH (26 October, AD 1669) (Bivar 1960: 203). The language of the glosses in all four Qurans was established as Kanembu, one of the dialects of Kanuri-a major Nilo-Saharan language spoken mainly in north-east Nigeria and the main language of ancient Bornu.

Although Kanuri was one of the first sub-Saharan languages to be documented, written sources prior to the early nineteenth century were generally believed to be limited to a short seventeenth-century word list recorded by a French traveller to the Bornu area and discovered in the Bibliothèque nationale de Paris (Lange 1972), and an even shorter seventeenth-century record of Kanuri words and phrases found in the works of the renowned Turkish traveller Evliya Çelebi (Habraszewski 1967). Whatever the significance of these two documents, the Bornu manuscripts, collected by Bivar in photocopied form, far exceed them in terms of the quantity and quality of linguistic and historical data. ${ }^{2}$ These manuscripts represent a rich and unique corpus of an ancient writing tradition which flourished in Kanem-Bornu, and give evidence for the Kanuri language as spoken over 300 years ago. The materials also provide a valuable historical insight into the key role of Kanuri/Kanembu scholars in the early development of Islamic scholarship and religious traditions in the

\footnotetext{
* I am much indebted to Professors A. D. H. Bivar and Philip. J. Jaggar for critical remarks and valuable comments on earlier drafts of this paper. I should also like to express my sincere gratitude to Dr P. Agoch for his most generous help with the English text of the paper. My special thanks to the anonymous referees for their most valuable remarks. Errors are mine.

${ }^{1}$ The Sultanate of Bornu was a powerful empire in the Lake Chad basin. Prior the fifteenth century it was a province of Kanem - an ancient centre of Islam in the historical Central Sudan. After Gazargamu was established as the capital of Bornu in 1480, the Sultanate of Bornu became the heir to Islamic culture in the area.

${ }^{2}$ There is also an additional quranic manuscript with Kanuri glosses, deposited in the Bibliothèque nationale de France, Paris. It was first described by F. Déroche as Arabic and possibly 'African' (see Déroche 1985: 48), then identified by N. Dobronravin as Arabic and 'Saharan' (Kanuri?). Thanks to the generosity of N. Dobronravin, it has subsequently been analysed in more detail by the present author.
} 
Kanem-Borno empire, historically one of the most extensive and powerful Islamic states in West Africa. ${ }^{3}$

Despite their scientific significance, however, historians and linguists have been largely unaware of the scale and content of these remarkable documents, and so they have never been analysed in any depth. Recently, however, thanks to the generosity and personal encouragement of Professor Bivar, I have been able to examine this collection of photocopied manuscripts in the Special Collections section of the Library of the School of Oriental and African Studies. The present paper summarizes the initial results of my research, and furnishes a general description of the collection, as well as preliminary views on the writing system and on some features of the language used in the glosses.

At present, thanks to the initiative of Professor Philip J. Jaggar, the study of the Bornu quranic manuscripts continues with the support of the AHRC research grants scheme under the title 'Early Nigerian koranic manuscripts: an interdisciplinary study of the Kanuri glosses and Arabic commentaries'. The project, hosted by SOAS, covers a three-year period (2005-08) and has the following objectives: a palaeographic study of the manuscripts; a linguistic analysis of the Kanuri glosses; expanding the existing corpus by means of research visits to northern Nigerian libraries, archives and private collections; digitization and systematization of existing manuscripts for analysis and long-term preservation; indexing and analysis of the digitized manuscripts and transcription of the Kanuri glosses and Arabic commentaries by means of structured storage in a database; creation and deployment of a web service application to access the database content for viewing, searching, and data analysis of text and graphics. The team of specialists involved into the project is: Professor Philip J. Jaggar (co-ordination and linguistic analysis), Professor A. D. H. Bivar (palaeography), Ms Rosemary Seton (archiving), Dr Dmitry Bondarev (linguistics and palaeography), Mr Abba Isa Tijani (project assistant, Kanuri dialects), Mr Daniel Vazquez-Paluch (Arabic/quranic studies).

\section{Description of the collection}

At present, Bivar's collection is deposited in the Special Collections department of SOAS library, inventory number MS. 380808. The SOAS corpus contains copies of three different manuscripts, two of which comprise more than 100 pages each, in microfilm form; the third consists of only four pages. ${ }^{4}$ The documents have been identified by the present author with regard to their content, and were given numbers and abbreviations which reflect the order in which they are now catalogued, and names of the owners of the original

\footnotetext{
${ }^{3}$ Arabic script, also known as Ajami (from Arabic 'ajam 'non-Arabs' by which the medieval Arabs referred both to 'incorrect' variants of the Arabic language and to non-Arabic texts in Arabic scripts, such as for instance Persian in the Middle East or Spanish in Andalusia), was adopted by many other communities in West Africa independently of the linguistic affiliation of their languages. According to Dobronravin (1999: 94) there were at least eight local traditions, each with its distinct features of writing, as follows: 1) Arabic script among the Fulani of the West Sudan (Pulaar area); 2) Arabic script among the Soninke (Azer); 3) Arabic script among the Wolof; 4) Arabic script among the Sooso and Manding; 5) Arabic script in the Volta river basin and among the Asante; 6) Arabic script among the Songay and Zarma; 7) Ajami of Kanem and Bornu in Saharan (Kanuri) and Chadic (Hausa and others) languages; 8) Ajami of Sokoto and Adamawa, mainly in Hausa and eastern dialects of Fula, and also in Yoruba and Nupe.

${ }^{4}$ Apart from the three manuscripts discussed in this paper, Bivar (1960: 199, 201; and in personal communication) mentions another. This manuscript, called 'Gwandu Quran', did not find its way to the collection.
} 
manuscripts (e.g. '1YM' means: manuscript, catalogue number 1, in the possession of Yerima Mustafa). In this section the content, physical state, and palaeographic properties of the documents will be described.

1) The 'Yerima Mustafa (Geidam) Quran' (henceforth 1YM, see Figures 1 and 2) - the manuscript shown to Bivar by Yerima Mustafa, the district head

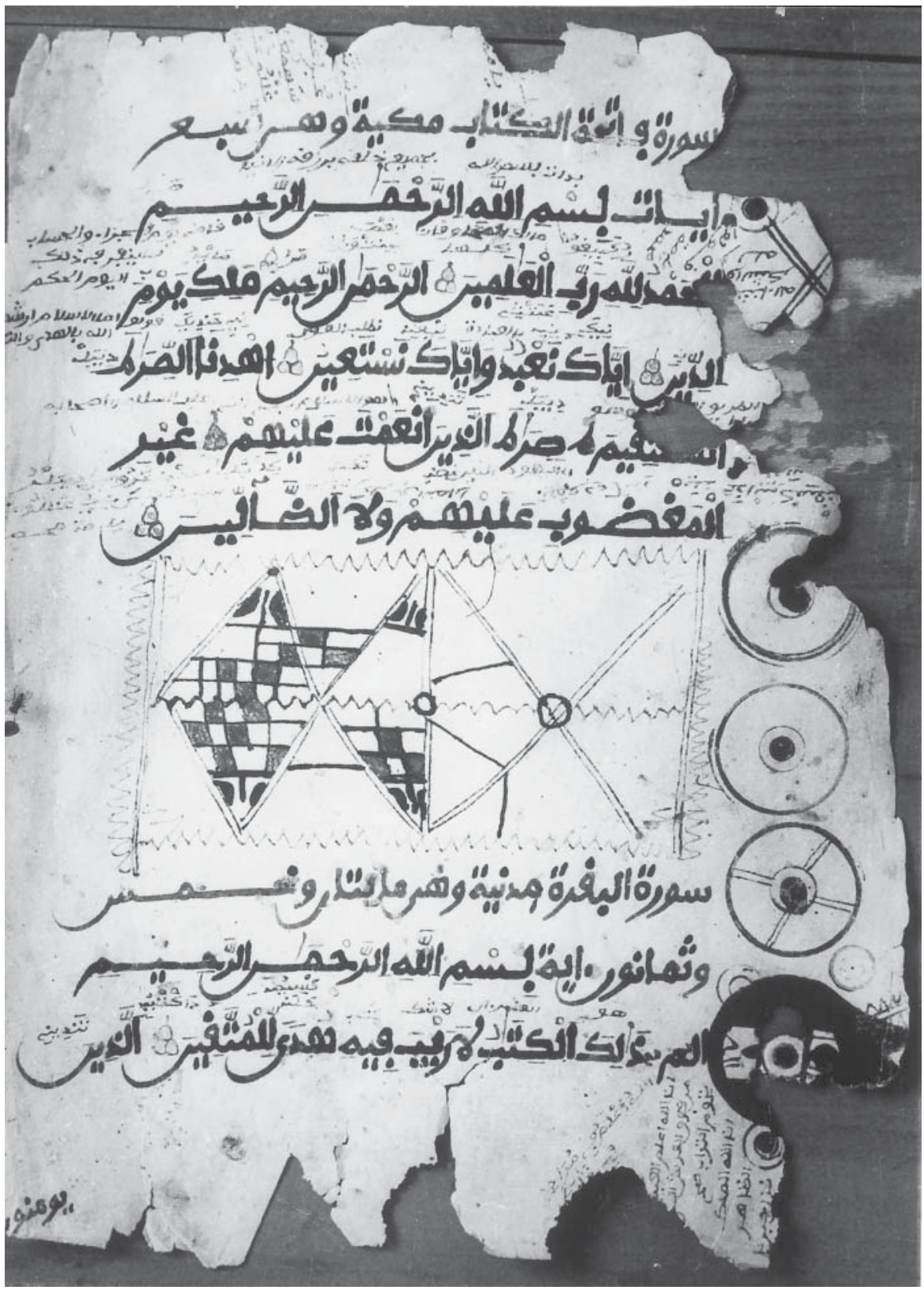

Figure 1. First page of the 'Geidam Quran' (manuscript 1YM) containing the first chapter sūra al-fätiha and the opening of the second chapter süra al-baqara. 


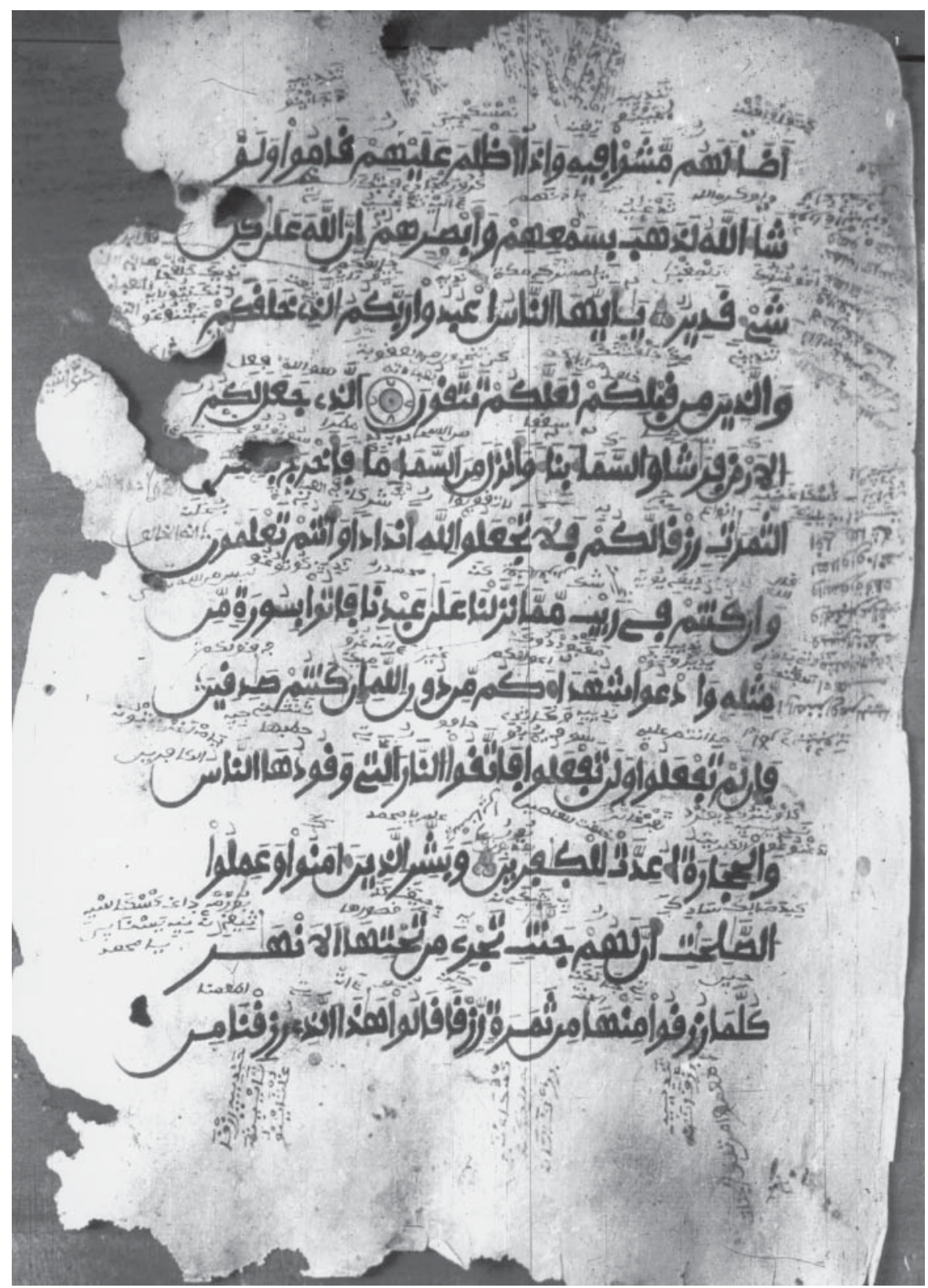

Figure 2. Fourth page of the 'Geidam Quran' (manuscript 1YM) containing ayats 20 to 25 of the second chapter süra al-Baqara.

of Geidam, a town in the north of Yobe State, Nigeria. The copy of the manuscript is preserved in microfilm, totalling three $35 \mathrm{~mm}$ rolls with $35-37$ frames each, making 105 pages in total. The majority of the frames are of good resolution, only a few of them having been blurred and a couple duplicated. This Quran is not complete. 
The content of the microfilms is as follows:

- film 1/6 (here and henceforth the library catalogue numbers are given)from sūra al-fätiha to verse 2:187;

- film 1/7-from Q.2:188 to Q.3:60;

- film 1/8 - the final süras from 92 to the end of the Quran.

There are also five specimen prints from 1YM, two of them on the bromide paper sheets marked as pages ' $\mathrm{B}$ ' and ' $\mathrm{C}$ '. The latter represents Q.28:85, the former has not yet been identified. The other three prints are mounted photographs signed 'Geidam Kuran', representing two initial pages of the manuscript (süra al-fätiha and first 12 verses of al-baqara) and the last page (süras 112-14).

Each page of $1 \mathrm{YM}$ contains a considerable number of Kanuri/Kanembu glosses. The glosses in Arabic are random and not extensive.

2) The 'Shetima Kawo Quran' (henceforth $2 \mathrm{ShK}$, see Figures 3 and 4) was shown to Bivar by Shetima ${ }^{5}$ Kawo of Maiduguri. This manuscript is represented by 36 negative prints and two microfilms in $35 \mathrm{~mm}$ rolls with 32 and 36 frames, 104 pages in total. The prints comprise consecutive pages from süra al-fattiha to Q.2:235 and a page of Q.93-Q.94. Most of the prints and the frames of the microfilms are of a very good resolution.

The content of the microfilms is:

- 2/37-consecutive pages from Q.2:176 to Q.3:36;

- 2/38 - random pages from Q.3:36 to Q.110:2.

The pages of manuscript $2 \mathrm{ShK}$ contain very many Arabic glosses taken from various tafsirs (yet to be identified), while the number of the Kanuri/ Kanembu glosses is relatively low.

3) The 'Imam Ibrahim Quran' (henceforth 3ImI, see Figures 5 and 6), which was in the possession of Imam Ibrahim of Maiduguri, is available in photographic copies comprising only four pages, three of which were published in 1960 (Bivar 1960: 200, 202). These positive prints, in multiple reproduction, show süra al-fătiha, two initial pages of süra al-baqara and the last page of the manuscript, with the colophon in Arabic carrying the date of completion of the tafsir.

Three of the four available pages carry extensive interlinear and marginal Arabic and Kanuri/Kanembu glosses, the marginal being less visible than the interlinear.

\section{Notes on the codicology and palaeography of $1 Y M, 2 S h K$, and $3 \operatorname{ImI}$}

Black-and-white photocopies do not provide a secure basis for a codicological analysis of the physical characteristics of the manuscripts, such as paper and ink colour. Nevertheless, the quality of most of the photographs makes it possible to identify some features without distorting the codicological facts. First of all, the manuscripts were written on paper of oriental origin. This can be established on the evidence of the laid and chain lines. The laid lines are visible on many pages of $1 \mathrm{YM}$ and $2 \mathrm{ShK}$, as well as sporadically on some pages of 3ImI. These lines are found to be very slim but dense. As for the chain lines, 


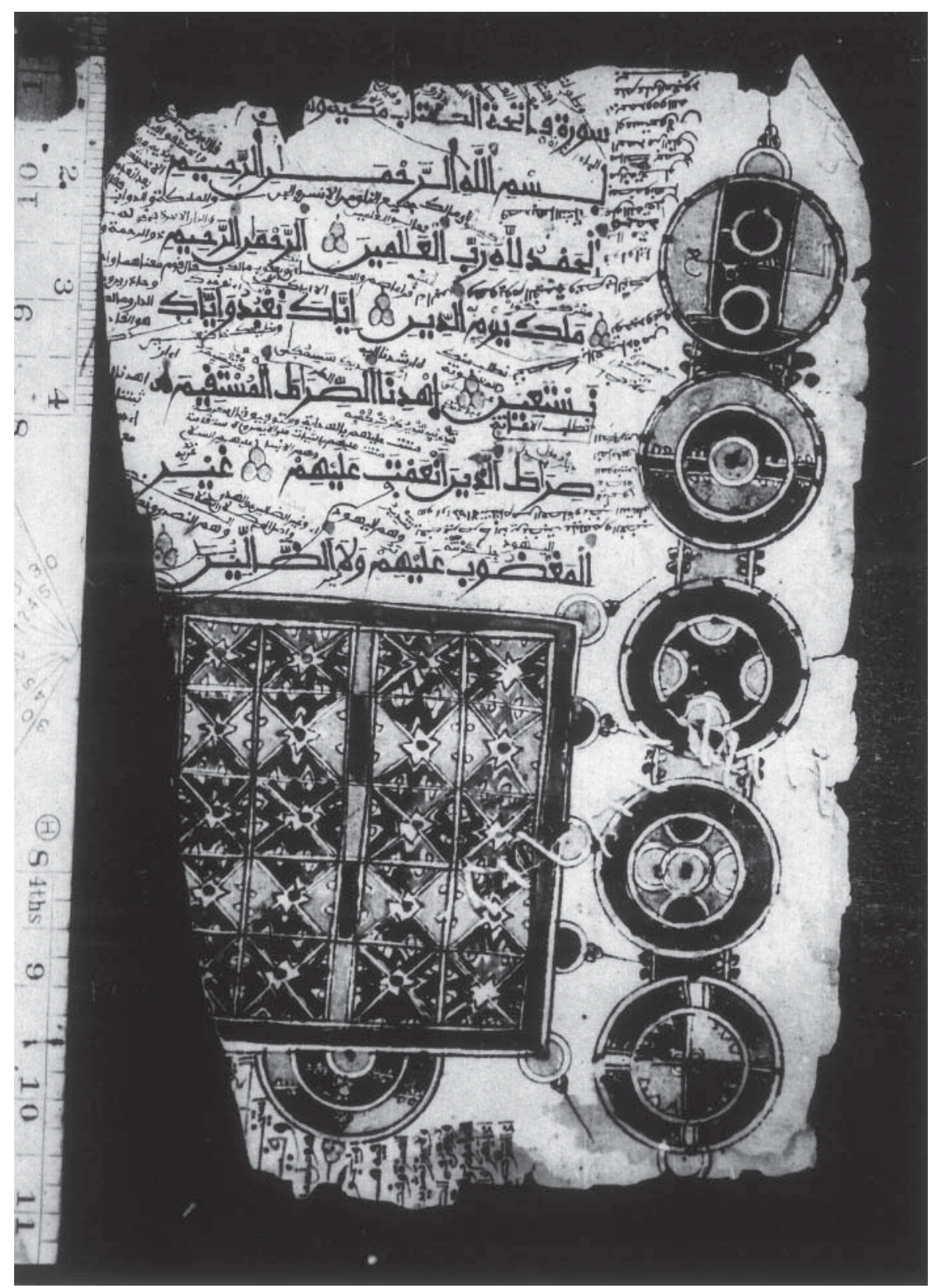

Figure 3. First page of the 'Shetima Kawo Quran' (manuscript 2ShK) containing the first chapter sūra al-fătiha.

they are much more difficult to distinguish, although they are easily visible on several pages of 1YM, irregularly spaced and arranged in groups of two or three. These parameters are distinctive and are typical of the oriental paper used in West Africa.

The size of the paper is approximately equal in all three manuscripts, which are in quarto size (about 13' $\left.\times 9^{\prime}\right)$. This is evident from Bivar (1960: 199) and from the scale rule applied while taking photographs of $2 \mathrm{ShK}$. In discussing 


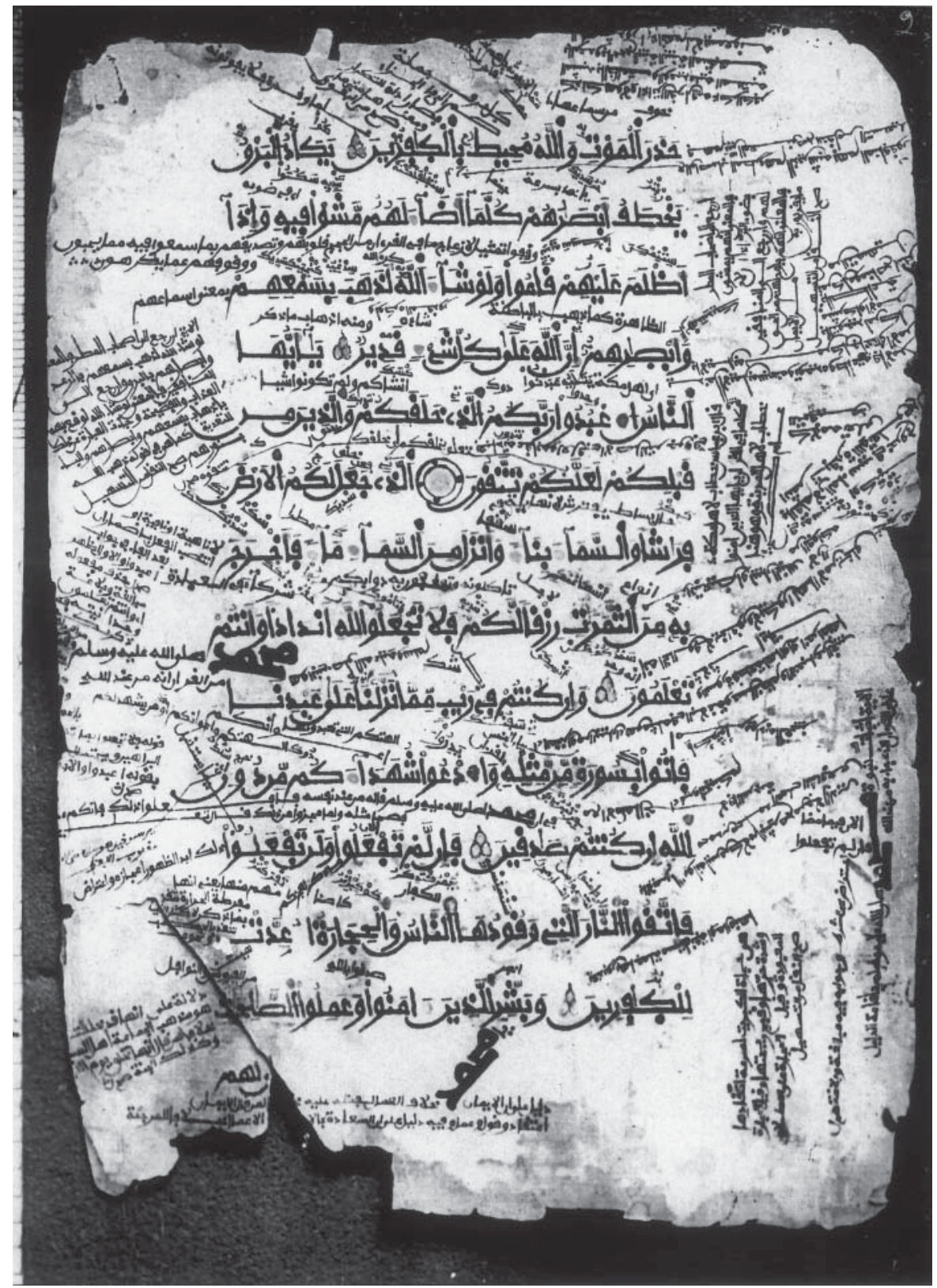

Figure 4. Fourth page of the 'Shetima Kawo Quran' (manuscript 2ShK) containing the ayats 19 to 25 of the second chapter süra al-baqara.

the size of the leaves, it should be kept in mind that most manuscripts are no longer their original size. The edges show signs of damage over time, although there are no signs of rebinding.

All three copies display wide margins. 3ImI has the widest margins, while the smallest are seen in $1 \mathrm{YM}$; those of $2 \mathrm{ShK}$ fall between these two in width. Table 1 provides comparative dimensions of the three manuscripts with numbers of lines per page. The first column shows the dimensions of the paper 


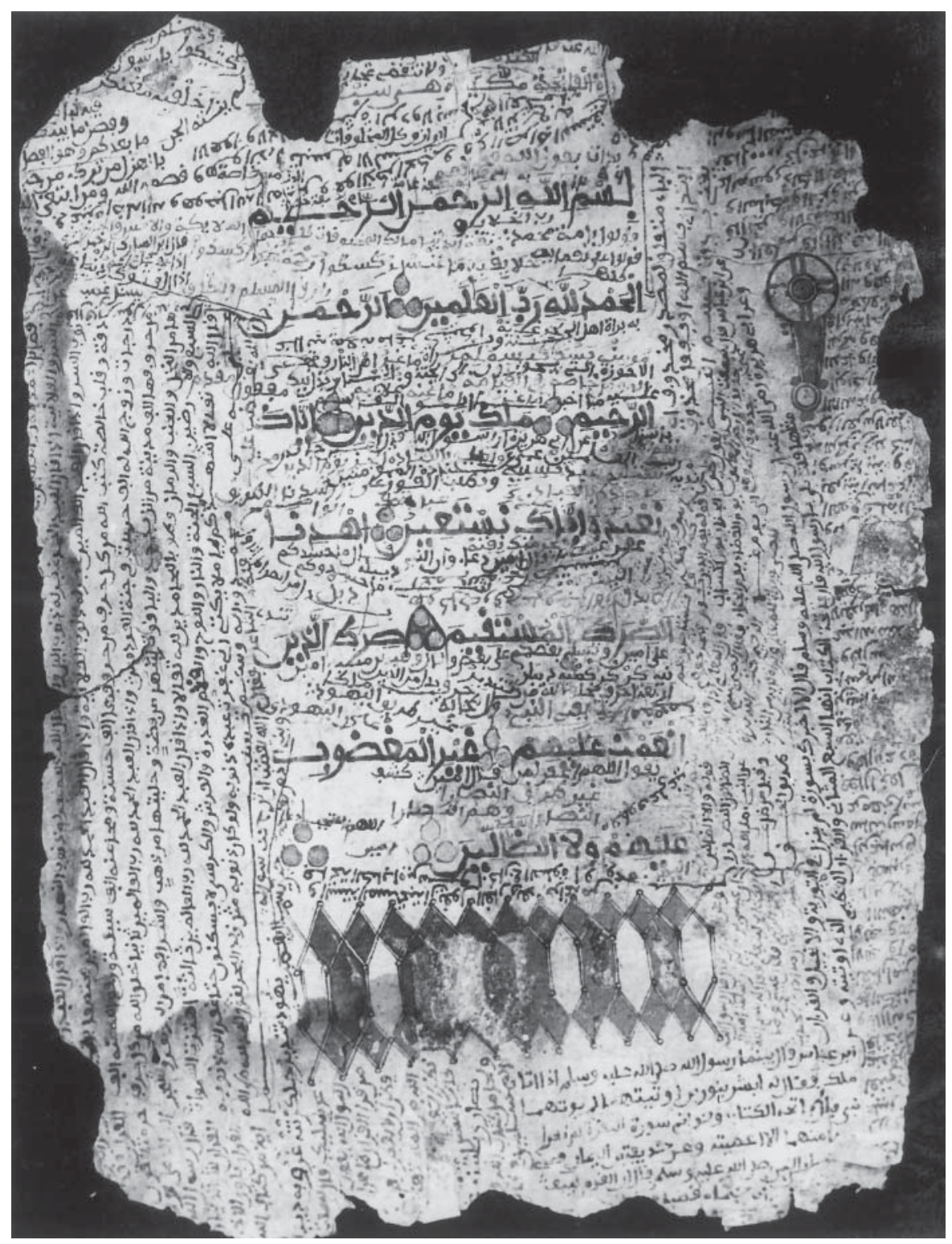

Figure 5. First page of the 'Imam Ibrahim Quran' (manuscript 3ImI) containing the first chapter süra al-fätiha (first published by Bivar (1960)).

(height is given first, then the width); the second the dimensions of the writing area (height of the text area is given first, and then the width of the line); the third the number of lines per page. The dimensions are given in inches.

With regard to palaeography, all three manuscripts belong to a calligraphic tradition of Bornu Court Hand, identified as such by Bivar (1968: 7) in his article on the transmission of varieties of Arabic script in West Africa. The most conspicuous features of this hand, which originates from the Kufic style, are worth citing here: 


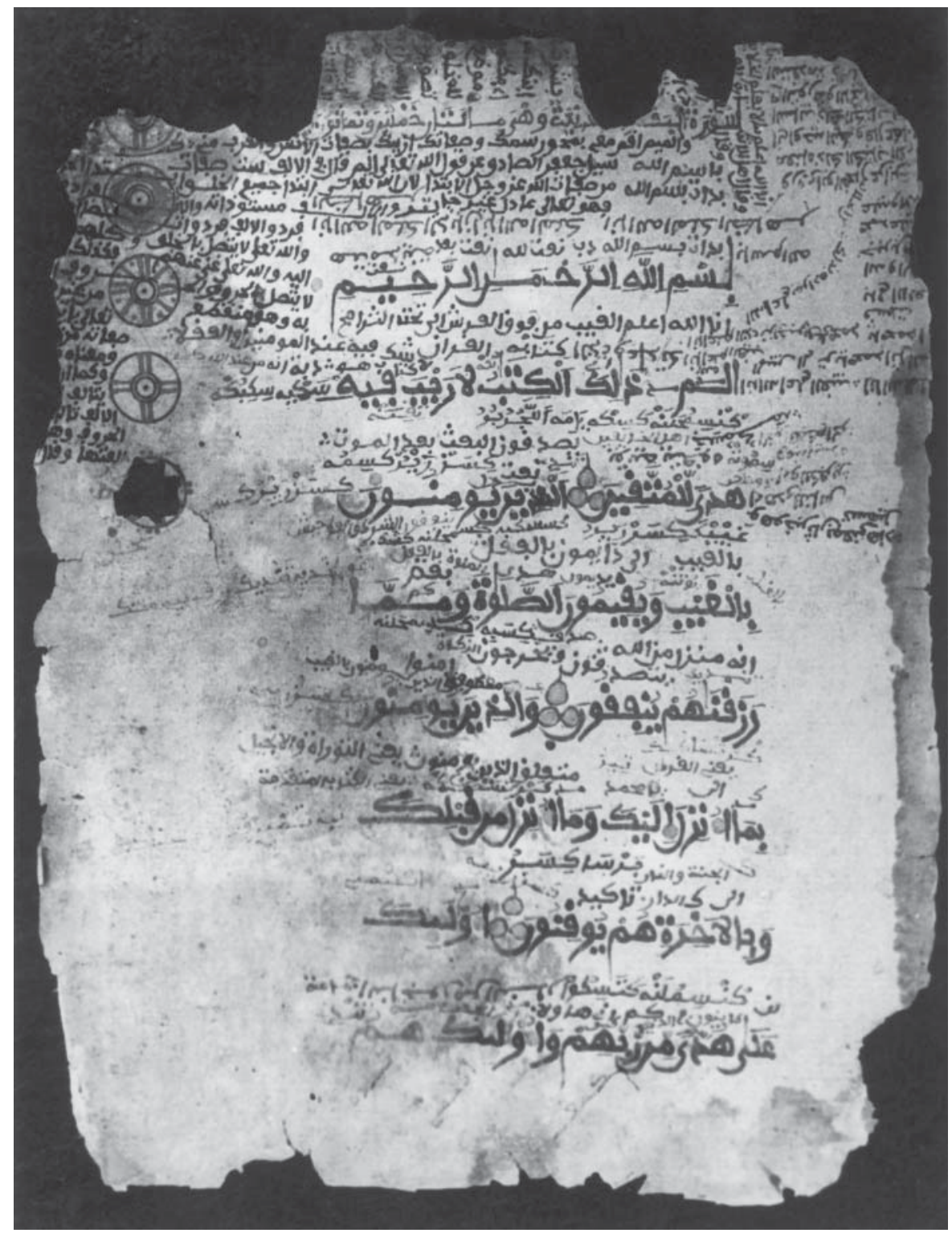

Figure 6. Second page of the 'Imam Ibrahim Quran' (manuscript 3ImI) containing he opening of the second chapter süra al-Baqara (first published by Bivar (1960)).

Noticeable is the thick, heavy line of the letters, and in particular the elongated form of the letter $k \bar{a} f$. The letter $q \bar{a} f$ and $f \vec{a}$, are as it were raised above the base-line of the script on a short stalk. The pointing, as in the great majority of authentically West African manuscripts is of the Western (Maghribi) type: $q \bar{a} f$ has a single point above, $f \bar{a}$ ' a point below. SSād and $d \bar{a} d$ run on smoothly after the loop, lacking the little tooth typical of modern printed Arabic, and the Eastern hand from which it derives. (Bivar 1968: 7). 
Table 1. The dimensions of the manuscripts

\begin{tabular}{llcl}
\hline MSS & Paper & Text area & Lines \\
\hline 1YM & $13 \times 9$ & $8.5 \times 6$ & 12 \\
2ShK & $13 \times 8.5$ & $8 \times 4.5$ & 12 \\
3ImI & $13 \times 10$ & $10 \times 4.5$ & $8-9$ \\
\hline
\end{tabular}

To this description the following distinctive characteristics should be added: the Bornu writing system does not use ligatures, except for joined lām and alif; the ascender of letter lām is reduced in height towards the base line; the descender of $y \bar{a}^{\prime}$ in isolated position is considerably reduced towards the base line (strictly speaking, only the upper portion remains). In word-final position, the letter is drawn as a hook turning back to the right towards the preceding letter, which is not typical of modern Arabic writing, where the descender of $y \bar{a}$ ' runs on to the left.

The three manuscripts also differ in their individual calligraphy. The lettering of 1YM and 3ImI presents a smooth 'rounded' style in contrast to 2ShK, which is more angular. With regard to the smooth style, there is a slight difference between 1YM and 3ImI, in that the former looks to have been produced by a more professional and confident scribe than the latter. That is to say the lines and the characters are more carefully formed in 1YM than in 3ImI. The two hands also differ in the density of letters per line: 1YM represents the denser manner, while letter-density in $3 \mathrm{ImI}$ is sparser.

$2 \mathrm{ShK}$ is remarkable not only for its more angular style, but also for its near perfect calligraphy. Some typological distinctions of this script can also be noted. The ascender of lam is not as reduced towards the base-line as it is in 1YM and 3ImI, being confined only by the ascenders of the other letters (alif, $k \bar{a} f$ etc.). The letter $k \bar{a} f$ is more elongated than in $1 \mathrm{YM}$ and $3 \mathrm{ImI}$. The letters $r \vec{a}$ and $z \vec{a}$ run on with a stronger curve at the level of the base line and show a tooth with a taller stroke above the base line. Interestingly, 3ImI, though less painstakingly made, shows the same forms of letters $r \vec{a}$ and $z \vec{a}$.

$1 \mathrm{YM}$ and $2 \mathrm{ShK}$ both have catchwords at the foot of each page. In 1YM the catchwords, diagonally positioned in the bottom left-hand corner of the page, are written in a hand more delicate than the heavy script of the main text. The catchwords of $2 \mathrm{ShK}$ are written straight below the last line and in the same script as the main text.

Thus far, I have discussed the actual text of the Quran. The extensive Arabic commentary on the Quran to be found in the manuscripts is beyond the scope of this paper. ${ }^{6}$

Now I shall address the Kanuri/Kanembu glosses. With regard to the hand of the glosses, the first point of note is that the glossing hand of $2 \mathrm{ShK}$ is extremely close to that of the Quran text. Whether this identity is the result of the same hand or of a strong calligraphic tradition has yet to be established. The glosses in 1YM are most probably written in a different hand from that of the primary text; but the former is very similar to the latter in style throughout the manuscript, with the exception of the glossing hand of the last pages. This is characterized by the greatly extended teeth of the letter $\sin$.

Manuscript 3ImI, especially its first page, is provided with extensive glosses in a number of different hands.

\footnotetext{
${ }^{6}$ For a preliminary description, see Bivar (1960: 201, 203).
} 
Table 2. Kanuri consonantal phonemes (Yerwa dialect) ${ }^{7}$

\begin{tabular}{|c|c|c|c|c|c|c|c|c|c|}
\hline & bilabial & lab. dent. & del & alv. & alv. & pal. & palatal & velar & glottal \\
\hline plosive & b & & $\mathbf{t}$ & d & & & & $\mathbf{k} \mathbf{g}$ & ? \\
\hline affricate & & & & & & $\mathbf{j}$ & & & \\
\hline fricative & & f & $\mathbf{s}$ & $\mathbf{z}$ & sh & & & & h \\
\hline nasal & $\mathbf{m}$ & & & $\mathbf{n}$ & & & & & \\
\hline lateral & & & & 1 & & & & & \\
\hline rolled & & & & $\mathbf{r}$ & & & & & \\
\hline approximant & $\mathbf{w}$ & & & & & & $\mathbf{y}$ & & \\
\hline
\end{tabular}

As distinct from the Arabic commentaries, the Kanuri/Kanembu glosses in all the manuscripts are fully vocalized. In all three copies, the glosses appear both interlineally and marginally; and some are written upside-down.

\section{The language of the glosses: morphology and phonology}

As mentioned above, previous scholarship (Bivar 1960: 201) has identified the language of the glosses (henceforth LG) as a dialect of Kanuri. Leaving aside the question as to which particular dialect it belongs to (which is discussed in section VII), LG represents an older form of Kanuri. A brief note on some linguistic features of Kanuri will therefore prove useful before LG is described.

The phonology and morphology of Kanuri will be discussed where relevant to the description of the Bornu writing system, and to the deciphering of LG. Here we will describe those phonological and morphological features which are common to the Kanuri language in general as a cluster of dialects. Anything characteristic of a dialect or a group of dialects will be noted separately.

As the Table 2 shows, the Kanuri consonantal phoneme system contains none of the 'exotic' segments common in a number of African languages, such as implosive and ejective consonants.

The modern Kanuri vowel system consists of seven phonemes. Jarrett (1978) claims that the central vowel /o/ and the back vowel / $\Lambda /$ reflect an extinct short vowel series, while the other five vowels are reflexes of a long series, both series having contrastive function. Their deciphering might be complicated by the fact that Kanuri is a tonal language, with three distinctive tones: high, low and falling. ${ }^{8}$

Table 3. Vowel phonemes i

$\begin{array}{cc}\mathrm{e} & \mathrm{o}^{\mathrm{u}} \\ \mathrm{a} & \Lambda\end{array}$

\footnotetext{
${ }^{7}$ Based on Cyffer (1997: 22; 1998: 19) and Hutchison (1981: 17). This chart does not include allophonic realizations.

${ }^{8}$ The high tone is indicated here with an acute accent (e.g. á), the low tone is unmarked (a), the falling tone is marked by circumflex (â).
} 


\section{Syllable structure}

The morpho-phonological system interacts with the syllable structure; this is important for the analysis of LG.

The main syllable types are CV and CVC. Syllables without onsets (V) also occur, although they are restricted to word-final position (e.g. kamua: $[k a]_{\sigma}[\mathrm{mu}]_{\sigma}[a]_{\sigma}$ 'women'). The bisyllabic structures $\mathrm{CVCV}$ and $\mathrm{CVCVC}$ are optimal for Kanuri.

When deciphering the LG writing system, it is important to specify the position of consonant phonemes within a syllable. All consonants can be arranged in one of two different sets. The first represents only onset consonants, the second coda consonants. The first group comprises the following phonemes: $t, c, k, b, d, j, z, g, f, s, s h, h, P, w, y$. The second group is represented only by sonorants: $l, r, m, n$. Sonorants are not restricted to syllable-final position, and are also used initially. ${ }^{9}$ This phonotactic rule is systematic, with the exception of two cases where the syllable-final (or coda) position is available for non-sonorant consonants. The first exception is in class 2 verb roots with the syllable structure CVC (e.g. bak- 'beat', let- 'sleep', etc.), the second applies to a lexical category of specific phonaesthetic adverbs (ideophones) (e.g. bas 'only', fok 'whiteness', etc.).

Consonant clusters are not permitted by a phonotactic constraint. The only permissible clusters are prenasalized obstruent combinations occurring in word-initial position (like $m b$, nd and $n g$ ). It is not clear, however, whether these are monosegmental or bisegmental (Cyffer 1998: 19). All consonants that occur across syllable boundaries are syllabified after the first consonant (e.g. napcin: $[\text { nap }]_{\sigma}[\mathrm{cin}]_{\sigma}$ 'he/she sits down').

The phonological development of Kanuri is characterized by active sound change, mostly affecting consonants. ${ }^{10}$ From the diachronic point of view, this results in a relatively rapid change of the phonological appearance of the whole language (new alternation rules, new fusion alterations). For example, a process of regressive assimilation $/ s k />\mid k k /$ followed by the degemination $|k k|$ $>/ k /$ has affected the archaic 1 st $\mathrm{sg}$. subject morpheme $s k$ in verb class 1 . Over the last 70 years, as evident from the material collected in the early 1930s by Lukas, this process has yielded the phoneme $/ k /$ as an exponent of the subject morpheme in class 1 verbs (e.g. buskin (Lukas 1937: 190) > bukkin > bukin (modern Yerwa)). The direction of all phonological change must be taken into account and applied in reverse order when deciphering LG (roughly speaking: if $* b>w$, then $w$ in modern Kanuri corresponds to $b$ in LG).

The following examples illustrate phonological changes in the Yerwa dialect: ${ }^{11}$

\section{Assimilation:}

regressive: $s k>k k$ (yáskin > yákkin 'I drink', kaskê > kakkê 'mine')

progressive: $m n>m m$ (lénnómna > lénnómma 'I slept')

Palatalization (before the front vowels $i$ and $e$ ):

$s>\operatorname{sh}, j, c(s \hat{\imath}>\operatorname{sh} \hat{\imath}$ 'leg', létsin > létcin 'he/she sleeps')

$k>c$ (késa > césa 'sand'); ${ }^{12}$

${ }^{9}$ Hutchison (1981: 15), see also Jouannet (1982: 41-68).

${ }^{10} \mathrm{Cf}$. for example: 'The idiolectal variations and the enormous number of phonological rules ... lead to the assumption that the Kanuri language has been and still is undergoing rapid change' in Cyffer (1988/1989: 40).

${ }^{11}$ Based on Koelle (1854), Lukas (1937), Cyffer (1997) and Bulakarima (1997).

${ }^{12}$ Both forms are possible in modern Yerwa. A free alternation $|k| \sim[c]$ before front vowels also occurs in some other words, e.g. kéle céle 'livestock watering hole', kengîn cengîn 'pile up by scrapping the surface', kimê $\sim$ cimê 'red', kéllé céllé 'tripping with the foot', kété $\sim$ cété 'very early pre-dawn period when one eats before a day of fasting' (all the examples are from Cyffer and Hutchison (1990)). 
Consonant weakening:

degemination: $k k>k$ (kakkê > kakê 'mine', yákkin > yákin 'I drink');

voicing: $k>g, t>d, s>z$ (kámkada > kámgada 'they cut' (Past), táta > táda 'a boy');

lenition: $b>w($ díbal $>$ díwal 'a road'); $k>y / w(k o ́ k a d a>k o ́ w a d a$ 'they passed');

deletion (most typical of intervocalic $k$ and $g$ ): $k>\varnothing, \mathrm{g}>\varnothing$ (mákada $>$ máada 'they wanted', wanéke > wanée 'perhaps').

Dialects other than Yerwa give evidence of additional phonological processes, while some of the above phonological rules are not applied in certain dialects. Thus, the Manga dialect has affrication $s>t s$ and intervocalic lenition $t>d$. The Dagera dialect is characterized by spirantization $s>h$. In the Movar dialect the following features are observed: affrication with palatalization $s>$ $c, z>j$, vocalization $b>u$, vowel prothetic augmentation before a word-initial retroflex $t$ (liman > itiman). ${ }^{13}$ However, it is possible to summarize the major phonological processes common to all dialects: consonant weakening, palatalization, assimilation, retroflexation, and compensatory lengthening of both consonants and vowels. ${ }^{14}$

A specific problem of deciphering LG relates to Kanuri morphology. This is the problem of spacing. Dobronravin (1999: 21) hypothesized that 'the boundaries of a graphic word written in an inflecting language prove to be constant ... With regard to agglutinating languages, fused or separate writing of word-formants and compound words raises the most difficult problem [for scribes]'. LG corroborates this hypothesis in quite an interesting way.

Kanuri is characterized by both agglutinative and inflectional morphology. Fusional strategy is dominant in verb morphology, while agglutination is conspicuously evident in noun morphology.

The Kanuri verb is represented by two morphological classes (class 1 and class 2); each of which uses specific paradigms in both inflection and word formation. Class 1 verbs also comprise a sub-class of irregular verbs characterized by their unique morphological structure. None of the roots of class 1 verbs can be used separately as an independent (isolated) word form. The bound nature of the verb root is also relevant to the productive class 2 , but only if the verb is not derived from another lexical word class (e.g. class 2 verb root le- with a broad meaning 'to go' > lejîn 'he/she goes' > letá verbal noun 'going', but *le does not occur). As is typical of the fusional technique, the morpheme boundaries in verb inflection (as well as in verb derivation) are obscure and difficult to identify due to the fusion of adjacent morphemes. The examples given in Table 4 illustrate this phenomenon by comparing the inflection of four verb roots represented in four identical grammatical categories: the 1st sg.

Table 4. Comparison of inflection of verb roots

\begin{tabular}{llll}
\hline 1st sg. imperf. & 3rd sg. imperf. & 3rd sg. past & verbal noun \\
\hline yíkin & cîn & cáino & yo, njo, kənjo \\
rúkin & súrin & cúro & ru, kurû \\
gaákin & gayîn & kargawô & gawo \\
lénngin & létcin & létkono & letta, léttó \\
\hline
\end{tabular}

\footnotetext{
${ }^{13}$ Data from Bulakarima (1997: 72-4).

${ }^{14}$ Ibid., p. 71.
} 
imperfect, the 3rd sg. imperfect, the 3rd sg. past, and the verbal noun. Three of the verbs are class 1 ( $y i^{-}$' 'to give', rú- 'to see', gaá- 'to enter'), the fourth verb (lét- 'to sleep') is class 2.

It is important to note that due to the fusional technique in verb morphology all inflected and derived verb forms are written as a single graphic word in LG. However, further segmentation of any such graphic word into morphemes is rendered difficult by complex internal morphological changes in the verb.

As mentioned above, noun morphology is typically (with a few exceptions) agglutinative. The lexical base of a noun is always stable, notwithstanding the attached formative morphemes, e.g. ngulondó 'finger', ngulondó $+n$ 'finger' + locative/instrumental marker 'by finger', ngulondó + be 'finger' + genitive marker 'of a finger'. Morphemes are attached to the lexical base one at a time in a strict hierarchical order:

kəskawádəro < kəska+wá+də+ro

'tree' + PL + DET + IO

'towards those trees'

The morpheme boundaries in noun formations and noun phrases are therefore easily distinguished, with the exception of a few instances which are indistinguishable for purely phonological reasons.

Graphic noun forms occurring in LG are also easily segmented, whether they are written as one word or as several separate words.

\section{The system of graphemes used in the language of the glosses}

The Bornu writing system used to record the language of the glosses (LG) appears to have developed some spelling conventions. This fact, interesting in itself, may become a reliable criterion for the purposes of the phonological reconstruction of LG. However, the extent to which these orthographic conventions were applied is not yet clear. Any conclusion regarding the degree of unification/standardization can only be arrived at through a comparative study of the entire corpus of the glosses. In the meantime, the material studied thus far has yielded some preliminary and interesting results about the essential aspects of both the grapheme system and the phonological inventory of LG.

\section{Consonant graphemes}

Tables 5 and 6 represent two types of grapheme-phoneme consonant correspondence: the probable (Table 5) and the possible (Table 6). The main purpose of the tables is to serve as a test for further deciphering of LG, which will in due course certainly rearrange the content of both tables (especially the second). At the same time, the tables display the initial results of research on the graphemic representation of the phonemes of the LG language.

\section{Comments on the tables}

1. The position of consonants (initial, intervocalic, final) is specified with reference to vowel environment but without further distinction of vowel features, such as front, back, rounded, etc. It should be possible to establish a more precise consonant distribution following analysis of further material.

2. The diacritical sign sukūn is always transliterated as 'zero' vowel, which may cause confusion because this graphic sign was apparently used for 
Table 5. Probable grapheme-phoneme correspondences for consonants

\begin{tabular}{|c|c|c|}
\hline bā' & $/ \mathrm{b}-/, /-\mathrm{b}-/, / \mathrm{p} / ?_{?}^{15}$ & $\begin{array}{l}\text { bōko 'negative marker'(2ShK), bamnōgo } \\
\text { 'do not beat (2nd pl. imperative)' (1YM), } \\
\text { abatci 'he/she worships' (1YM), jabūybo 'they } \\
\text { do not eat'(1YM) }\end{array}$ \\
\hline tā' & /t-l, /-t-/ & tandī 'they'(all MS), fāto 'house' (1YM) \\
\hline dāl & /d-l, /-d-l & $\begin{array}{l}\text { dībalh 'road'(all MS), sādi 'they did' (1YM), } \\
\text { tandī 'they' (all MS) }\end{array}$ \\
\hline rā' & $/ \mathrm{r}-1,|-\mathrm{r}-/|-,\mathrm{r} /$ & $\begin{array}{l}\text { rayro 'for the soul'( } 3 \mathrm{ImI}) \text {, alaro 'to God' } \\
\text { (1YM), krmāiro (kərmāiro) 'for kingdom' } \\
\text { (1YM) }\end{array}$ \\
\hline $\sin$ & $/ \mathrm{s}-/, /-\mathrm{s}-/, /-\breve{s}-/$ ? & $\begin{array}{l}\text { sdìka (sədìka) '[if] he did'(2ShK), } \\
\text { musku 'hand' (1YM), kisulugo '[water] flowed' } \\
\text { (1YM), kansimohalan 'with a guidance'(4ImI) }\end{array}$ \\
\hline ghayn & /g-/, /-g-/ & $\begin{array}{l}\text { gule 'say!'(1YM), thmāgin (thomāgì) 'he } \\
\text { received' (1YM) }\end{array}$ \\
\hline fā' & $/ \mathrm{f}-/, / \mathrm{p} /$ ? $($ see note 16$)$ & fāto 'house' (1YM) \\
\hline kāf & $/ \mathrm{k}-/, \mathrm{l}-\mathrm{k}-/$ & $\begin{array}{l}\text { kntāg (kəntágə) 'month' (1YM), } \\
\text { tandīka 'them' (all MS) }\end{array}$ \\
\hline lām & $/ 1-/, /-1-/, /-1 /$ & $\begin{array}{l}\text { lan 'locative marker' (1YM, 3ImI), gule 'say!' } \\
\text { (1YM), tilò 'one, single' (1YM), dībal 'road' } \\
\text { (all MS) }\end{array}$ \\
\hline $\operatorname{mim}$ & $/ \mathrm{m}-/, /-\mathrm{m}-/, /-\mathrm{m} /$ & $\begin{array}{l}\text { mai 'a title of a Kanem/Bornu ruler' ( } 3 \mathrm{ImI}) \text {, } \\
\text { kuma 'lord, master' (3ImI), bamnoggō '[you } \\
\text { pl.] beat!'(1YM) }\end{array}$ \\
\hline nūn & $/ \mathrm{n}-/, /-\mathrm{n}-/, /-\mathrm{n} /$ & $\begin{array}{l}\text { nadīlan 'with (?) you pl.' (1YM), kntāg } \\
\text { (kəntágə) 'month' (1YM) }\end{array}$ \\
\hline wāw & $/ \mathrm{w}-/, /-\mathrm{w}-/$ & $\begin{array}{l}\text { waka (to be identified) (2ShK), kamuwa } \\
\text { 'women' (1YM) }\end{array}$ \\
\hline yā' & $/ \mathrm{y}-/, /-\mathrm{y}-/$ & $\begin{array}{l}\text { yenōgo '[you pl.] respond!' (1YM), jaksiyah } \\
\text { 'when he covers' (1YM) }\end{array}$ \\
\hline
\end{tabular}

conveying two different phonological realities: a consonant followed by a consonant (e.g. $k+s$ in the gloss jaksiya 'when he will cover'), and a consonant followed by a vowel (e.g. the gloss kntāg which corresponds to Kanuri kəntágə 'new moon'). Kanuri syllable structure (see section III, above) does not permit analysis of the last example (kntāg) as having only one syllable with the vocalic nucleus $\bar{a}$. Neither a word-initial cluster $k n$ nor a word-final $g$ are possible within a Kanuri word. For this reason all the glosses bearing sukün as a vowel mark are accompanied in the tables by a relevant fully specified vowel form of the encoded word (in parentheses). The phonological quality of the vowels represented by sukün is discussed later.

3. The letter $h \bar{a}$ ' (not to be confused with $h \bar{a}$ ) is used in $1 \mathrm{YM}$ and $3 \mathrm{ImI}$ to encode the first syllable of the 2 nd pl. personal pronoun handī which

${ }^{15}$ It is possible that LG had a conditioned allophonic alternation $/ b / \sim[p]$ (before voiceless plosives), and a free allophonic alternation $|f| \sim[p]$ as occurs in some modern Kanuri dialects. The Bornu writing system did not create a specific character for conveying the sound $p$, which means that such a sound might have been encoded in a homophonic order (two different letters for one sound). In this case one would expect that the graphic realization of a hypothetical sound $p$ should be shared between the letters $b \vec{a}$, and $f \vec{a}$. 
Table 6. Possible grapheme-phoneme correspondences for consonants

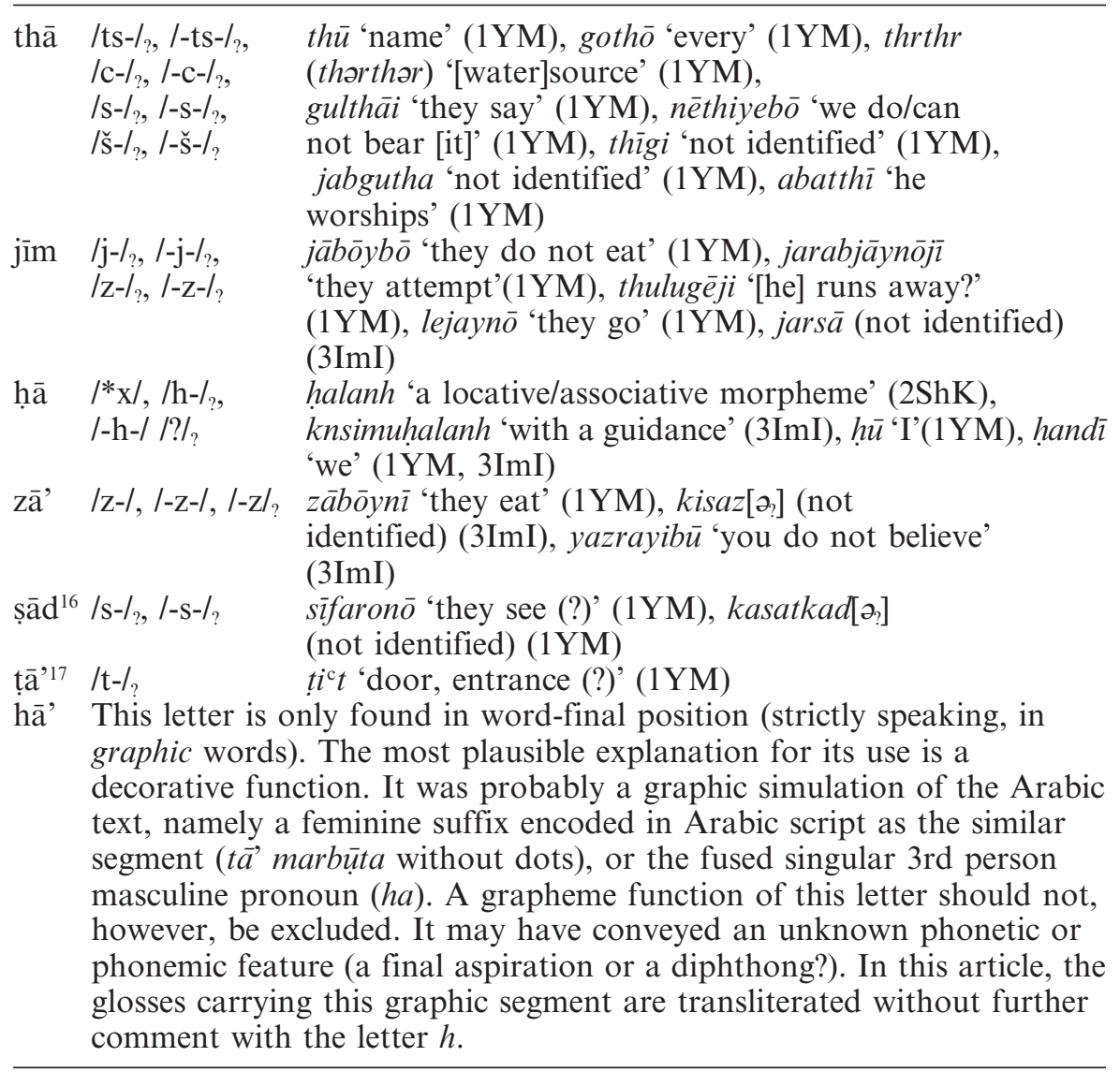

corresponds to the modern form andi 'you pl.'. It is most unlikely that the combination of $h \bar{a}$ ' and fath $\bar{a}$ was used for encoding initial /al: this graphic combination $(h+a)$ is restricted to just two glosses hāndi and hālanh which occurred regularly throughout 1 YM and 3ImI. Since the rest of the glosses containing initial $/ a /$ are recorded with other letters (see below), there is good reason to think that the letter $h \bar{a}$ is the unique encoder of a consonant sound, rather than the non-phonemic onset articulation of the initial phoneme $/ a /$. This phenomenon is discussed in section $\mathrm{V}$.

Graphemes used only in Arabic borrowing: shin, zāad, qāaf.

Graphemes not found in $L G$

khä, dhāl.

Vowel graphemes

The deciphering of the LG vowel phonemes raises several specific problems. The first relates to the fact that the Bornu writing system does not distinguish between the back rounded vowels $/ \mathrm{o} /$ and $/ \mathrm{u} /$, both of which are conveyed by

\footnotetext{
${ }^{16}$ Also in borrowings: e.g. așiyāmka from Arabic, al-siyām 'fast'.

${ }^{17}$ It occurs more often in borrowings, e.g. țălütyih (1YM) from Arabic, țālūtu 'Saul'.
} 
damma. The modern reflexes of decoded glosses may certainly be helpful in solving this problem (e.g. m(damma)sk(damma) corresponds to musko 'hand' and $r$ (damma) corresponds to ro 'indirect object'). But there are obscure glosses with graphic endings marked by damma for which no correspondence has yet been established (e.g. r(damma) kafigh (damma) + the letter wāw and the letter alif).

The second problem is connected to tone marking. The question whether the Bornu writing system distinguishes tones is still open. If it does so, then to what extent? Does it work on a regular basis, or is it optional? For example, in a number of morphemes the vowels are regularly encoded by the weak letters alif, $w \bar{a} w$ and $y \bar{a}$. This regularity is observed in the following cases: imperative suffix $g \bar{o}$ (Kanuri -wó), the second syllable in the plural person pronouns $d \bar{\imath}$ (Kanuri -di ), the possessive suffix $n \bar{\imath}$ (Kanuri -nyí), and in some other instances. These examples show that the long syllables (in graphic form) of the morphemes of the LG correspond to the modern Kanuri high tone syllables in these respective morphemes.

The question of tone marking may be even more complicated. As mentioned in section III, the hypothetical vowel system of LG might potentially comprise two series: long and short. If this is the case, we may expect that weak letters were also used to encode long vowels (as in Arabic). And if so, was the writing system at all 'sensitive' to high tone syllables? In other words, which particular feature do the weak letters represent: high tone, long vowels, or both?

The present stage of analysis does not provide evidence in favour of a contrast between long and short vowels. The main argument against a twoseries system in LG appears to lie in the graphic marking of the 'zero vowels'. The diacritical mark sukūn, with the exception of its conventional usage (i.e. marking a consonant not followed by a vowel), encodes a vowel phoneme or phonemes, the reflex of which in modern Kanuri is / $/$ /. According to the hypotheses of Jarrett (1978: 28-31), modern Kanuri /a/ emerged as a result of laxing and neutralization of short vowels (i, e, $\mathrm{u}, \mathrm{o})$ to this central vowel. If LG did show a contrast between long and short vowels, it is difficult to explain why the Bornu writing system did not distinguish between short vowels, representing all of them with the same sign (sukün), despite the Arabic script itself using a clear graphic system for the long/short distinction. On the contrary, if the vowel system of LG was not characterized by a contrast between long and short vowels, and the central vowel /o/ was a contrastive component of this system, the explanation of sukün as marking a vowel is self-evident: this diacritic represented the phoneme /o/.

With regard to the vowels $/ a /$ and $/ i /$, in word-medial and final positions they are generally marked respectively by the standard Arabic signs for vocalization, fatha and kasra. For additional characteristics (length, tone, or both?) of the vowels $|a|,|i|, \mid o /$ and $\mid u /$, the weak letters are used (alif, $w \bar{a} w$, and $y \bar{a}$ ).

In word-initial position only the phonemes /a/ and /il occur, which is not at variance with the phonotactic rules of modern Kanuri. The initial vowels are represented by letters alif, hamza in conjunction with alif, and isolated hamza:

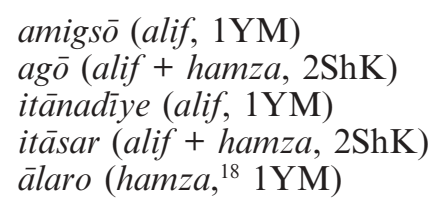

${ }^{18}$ Isolated hamza looks more like the isolated letter ${ }^{\mathrm{c}}$ ain. 
The vowels $/ e /, / o /$, and $/ u /$, do not occur in word-initial position. The same constraint, with the single exception of the word $u w u$ 'five', is also relevant to modern Kanuri. It would be of palaeographic interest to see what graphic solution the writing tradition applied for marking word-initial /u/, but the word $u w u$ 'five' has not yet appeared in the manuscripts.

The vowel /e/ is represented by imāla - a dot below the letter. This diacritical sign is typical of Arabic script, which uses it for fronted /al and /el. A prosodic/quantitative counterpart of /e/ (long or high?) is indicated by imäla and the $y \bar{a}$ ' with the slant alif above.

There is a word-final combination alif + sukūn used after long $|\bar{u}|$ or $|\bar{o}|$

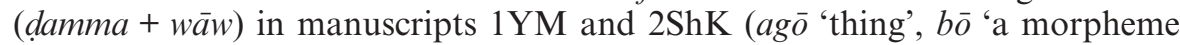
of negation'). It is not clear what this combination was used for, and how regularly it was applied.

The combination of sukün and the $y \bar{a}$ ' which follows the preceding long $\bar{a}$ (alif after fatha) represents the diphthong ai (e.g. mäi 'king').

It should also be mentioned that there is a specific order for marking a consonant without a following vowel. It relates only to words with the letter $n \bar{u}$, which is often written without a diacritical mark. In this case, it means that the nūn is not followed by a vowel. This graphic convention can be considered regular for plural personal pronouns (e.g. tandī 'they'). Other graphic words and segments may also optionally have the same function of the $n \bar{u} n$ (e.g. kntāg 'new moon', lan 'locative postposition'). This spelling convention is not characteristic of the glosses in $2 \mathrm{ShK}$.

\section{$\mathrm{V}$. The interpretation of selected glosses from $3 \operatorname{ImI}$}

In this and the following sections, selected examples of glosses will be discussed in some detail and examined as to their phonological and morphological properties. Lexical and semantic questions will be treated in a separate article.

A line of the glosses from the first page of 3ImI was interpreted in Bivar (1960: 203). Most of the extensive glosses seen on three of the four pages of 3ImI are still obscure, although several words and some noun phrases have been deciphered. Here I will discuss only one set of the glosses from this manuscript.

Page 2 of $3 \mathrm{ImI}$ represents the first verses of sūra $2 .{ }^{19}$ Two glosses related to verses 2 and 5 (henceforth Q.2:2 and Q.2:5) are almost identical. The only difference is a graphic segment ha (see Table 7).

Table 7. Glosses on page 2 of $3 \mathrm{ImI}$

\begin{tabular}{|c|c|c|}
\hline $\begin{array}{l}\text { Place (manuscript } \\
\text { and number of } \\
\text { sūra and verse) }\end{array}$ & Quranic text & Gloss \\
\hline 3ImI, 2:2 & $\begin{array}{l}\text { dhälika-l-kitāb lā rayba fìhi hudan } \\
\text { li-l-muttaqina 'This is the Scripture } \\
\text { wherein there is no doubt, } \\
\text { a guidance..., }\end{array}$ & knsimohalanh \\
\hline 3ImI, 2:5 & $\begin{array}{l}\text { 'ülàika 'alä hudan min rabbihim 'These } \\
\text { depend on guidance from their Lord.' }\end{array}$ & knsimolanh \\
\hline
\end{tabular}

\footnotetext{
${ }^{19}$ In Bivar's classification, page (b).

${ }^{20}$ The translation of this verse and those of other verses in this paper are taken (unless indicated otherwise) from Pickthall (1999).
} 
Before discussing the problem of the segment ha observed in gloss Q.2:2, it should be noted that both glosses are connected with the Arabic term hudan 'guidance'. There is good reason to consider the initial identical parts of both glosses, knsimo, as a noun semantically connected to the Arabic term. Modern Kanuri (Yerwa dialect) has two words which most probably relate historically to the given gloss. These are:

1. a class 2 verb shimongîn ${ }^{21}$ 'guide', 'direct', 'show the way' with the content morpheme shimo- of which there is no isolated occurrence;

2. a noun kashímo 'guide', 'instructions', from which a verb kashimongîn 'guide', 'direct' is derived.

The gloss knsimo can be further split into a non-productive prefix $* k n$ ( $k$ n) (reconstructed by Hutchison (1981: 75-6) as *k/V/C-in Yerwa Kanuri, where $C$ is a sonorant consonant), and a root simo, the reflex of which is the morpheme shimo. ${ }^{22}$

As to the second part of the graphic word knsimolanh, namely lanh, it can clearly be interpreted as a locative marker (modern locative-instrumental suffix -lan, henceforth LOC). The first reason for this relates to the Arabic noun phrase 'ala hudan 'on the guidance', where the preposition 'ala conveys a locative-instrumental meaning. Translation of this phrase into Kanuri would logically require the locative suffix -lan. The second reason is based on the analysis of $1 \mathrm{YM}$, which provides a number of examples of a similar use of the graphic element lanh (or lan) for conveying the Arabic preposition 'ala 'on'. For instance, the Arabic phrase 'alaykum (lit. 'on you' pl.), made up of the preposition 'ala 'on' and a fused 2nd pl. m. pronoun -kum, is consequently represented in LG as the 2 nd $\mathrm{pl}$. pronoun nadi (Kanuri nandi) and the same suffix -lan, i.e. nadilan.

Thus we have sufficient evidence for both the initial and final parts of the graphic word knsimulanh, and its translation, which reads 'on/with the guidance'.

Interpretation of the gloss knsimohalanh written above 2:2 is rendered difficult by an additional graphic element $h a$. There are two possible explanations: 1) ha may be the initial syllable of an obscure morpheme halan, which is now extinct; 2) ha may be a separate morpheme equivalent to the Kanuri associative marker $-a$ (or - $C a$ in underlying form).

Both explanations are based on my assumption that the gloss knsimohalanh conveys the Arabic noun phrase fihi hudan, lit. 'in this [there is] a guidance'. This assumption is not straightforward because the Arabic verse (Q.2:2) permits various interpretations. The verse reads:

dhālika-1-kitāb lā rayba fỉhi hudan li-1-muttaqīna.

'that' (DEM)-'the'-'book', 'no', 'doubt', 'in-this', 'guidance', 'for', 'those who ward off'

'This Scripture wherein there is no doubt, a guidance unto those who ward off (evil).'

The problem lies with the ambiguity of the role of the anaphoric fini in this'. Syntactically it could refer to three different clauses, allowing three alternative readings:

\footnotetext{
${ }^{21}$ Kanuri verbs are given in the first person singular forms of the imperfect.

${ }_{22}$ The manuscript 2 ShK gives evidence of the similar gloss written above the same quranic term hudan in Q.2:5: kasimolan. It should be noted that the prefix has no sonorant consonant and is vocalized by fatha lal.
} 
1) Anaphoric fihi, if taken as part of the incidental clause, refers to the whole phrase, leaving 'the book is guidance' as the main clause: 'This book, no doubt in this, is the guidance'. Cf. translations based on this interpretation: 'This is the Book (the Quran), whereof there is no doubt, a guidance to those who are Al-Muttaqoon'. ${ }^{23}$

2) The anaphora links la rayba 'no doubt' as predicate to the antecedent 'the book', with hudan 'guidance' an appositive noun: 'This [is the] book wherein there is no doubt; [this is] the guidance'. Cf. translation of Muhammad M. Pickthall (1999): 'This Scripture wherein there is no doubt, a guidance unto those who ward off (evil)'.

3) The anaphora links hudan 'guidance' as predicate to the antecedent 'the book' making 'no doubt' an incidental clause: 'This [is the] book, in this, no doubt, is the guidance'. Cf. translation which is based on this syntactic interpretation: 'This is the Book, in it is guidance sure, without doubt, to those who fear Allah'. ${ }^{24}$

If $f i h i$ was interpreted by the author of the tafsir as part of an incidental clause (reading 1), the main utterance would have been translated as an equational construction:

dhālika-1-kitāb hudan

that (DEM) book guidance

'that book is a guidance'

In this case, the predicate hudan 'guidance' would most probably be conveyed by an isolated noun knsimo, because the Kanuri identificational constructions logically expected here are formed through the simple juxtaposition of constituents. ${ }^{25}$

If $f i h i$ was interpreted as linking la rayba 'no doubt' as predicate to the antecedent 'the book' (reading 2), the word hudan 'guidance' would have been interpreted as an appositive noun. In this case, as in the previous example, an isolated use of the noun knsimo would also be expected in the translation of Q.2:2.

Even so, we must remember that the word knsimo is written with grammatical formants (or a formant) and has the graphic shape knsimohalanh. As an explanation of this contradiction I suggest that the author of the glosses (following a particular tafsir tradition (?)) glossed the verse according to reading (3): 'in this [book] there is a guidance'. Only this reading could make the noun knsimo into a modifier which takes a postposition modifier marker (cf. in Kanuri: associative marker $-a$ in kitawu kashimo- $a$ 'a book with a guidance'). ${ }^{26}$

As to the morphological nature of the graphic segment halanh, it may represent an unknown morpheme *xalan, the syntactic properties of which are yet to be explained.

\footnotetext{
${ }^{23} \mathrm{http} / / /$ www.equran.org/qrn/view/mohsin/2.html (18.04.2004).

${ }^{24} \mathrm{http}: / / \mathrm{www}$. intratext.com/ixt (18.04.2004).

${ }^{25} \mathrm{Cf}$. a modern equivalent of the phrase 'this book is a guide': kitawu ado kashimo.

${ }^{26}$ There is further proof for this suggestion. The most common quranic reading used in West Africa was Warsh. According to the tafsir of Ibn Juzayy (198-?: 35), the Warsh reading, which has a pause mark (waqf) after la rayba, separates the verse into two sentences: 1) dhālika-l-kitāb lā rayba; and 2) fihi hudan li-l-muttaqina. This reading ascribes anaphoric fihi the same syntactic function as in the suggested reading (3) ('in this there is a guidance'). I am grateful to Mr Daniel Vazquez-Paluch for his generous help in this issue.
} 
There is also another possible option: halanh may represent two conjoined ASSOC and LOC suffixes. ${ }^{27}$ In this case the morphemic segmentation of the gloss knsimohalanh would be:

knsimo-ha-lanh

guidance-*ASSOC-*LOC

*'[the book] with the guidance in [it]'

The problem cannot be successfully solved, however, until an isolated usage of ASSOC has been found in LG.

A tentative confirmation of the suggestion that the gloss knsimohalanh reflects a specific reading of the Arabic phrase is found in two other manuscripts. 1YM and $2 \mathrm{ShK}$ in Q.2:2 give evidence of the same usage of the graphic segment halanh as found in 3ImI, though this segment is written separately (this is an example of graphic segmentation occurring in noun phrases (see section III). ${ }^{28}$ The most interesting point, however, is the confirmation of the interpretation of the discussed anaphoric element fihi in Q.2:2. In 1YM we find the Kanuri gloss kitab 'book' written right on top of the anaphoric fihi 'in it/this', explaining the meaning of a syntactically ambiguous pronoun - $h i$ 'this' and referring it to its antecedent kitāb 'book'. Following the interpretation given by the scribe here we can therefore confidently exclude reading (1) from the possible Bornu interpretations.

As stated in section IV, the sound represented by the letter $h \vec{a}$ ' (so far observed in halan) is of special interest. The present analysis of LG shows that this letter is, with the exception of two genuine Kanuri words, used only in Arabic loanwords. These are the 1st sg. and 1st pl. personal pronouns, written as $h \bar{u}(1 \mathrm{YM})$ and handī (1YM and 3ImI) respectively. Such restricted distribution of the letter $h \bar{a}$ gives some ground for considering the phonological status of the first segment as common to these two pronouns. It has already been argued (in section IV) that the $h \bar{a}$ encoded a consonant phoneme rather than a non-phonemic feature of the onset articulation of an initial vowel. The comparison of the reflexes of the given pronouns in different dialects provides us with the correspondence of the initial segment as follows:

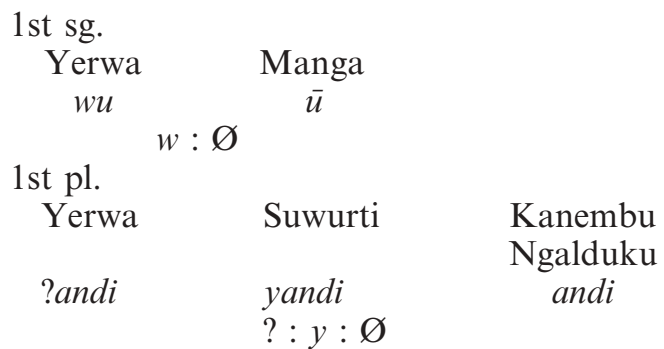

${ }^{27} \mathrm{Cf}$. modifiers arrangement in the modern Kanuri phrases (Yerwa dialect):

fáto dâ-a-lan

'house', 'meat'-ASSOC-LOC

'in a house that has meat'.

Nâ tomamá-a-lan tígə-nəm gámbombâ

'place', 'an expectant person'-ASSOC-LOC, 'body'-2nd Sg. POSS, 'scratch'-2nd Sg. IMPERF.NEG

'One doesn't scratch oneself when around an expectant person (e.g. beggar)'

For this example, see Hutchison (1981: 199-200).

${ }^{28}$ The segment halanh is adjacent to the word ksimo in $1 \mathrm{YM}$ and to the word simotwa in $2 \mathrm{ShK}$, the latter most probably being a verbal noun derived from a class 2 verb with the meaning-carrying morpheme *simo. 
I assume that LG preserved an extinct consonant phoneme (tentatively *x) which subsequently weakened in the dialects to a glottal stop, approximant, or zero. This phoneme may be considered as a remnant aspiration of two different proto-Kanuri phonemes: ${ }^{*} k\left({ }^{*} k^{\mathrm{h}}\right.$ ?) for the $1 \mathrm{st} \mathrm{sg}$. and $* t$ for the $1 \mathrm{st}$ pl. ${ }^{29}$

Among other personal pronouns the 2nd pl. (nadī in 1YM, nandi in most modern dialects), the written form of which is difficult to interpret phonologically, is worth mentioning here. All plural forms of the Kanuri personal pronouns have a common element -and- (cf. Kanuri Yerwa: andí, nandi, sandi). This element is overtly represented in the writing of the 1st pl. (handi) and the 3 rd pl. (tandī), but not the 2 nd pl. (nadī). There are no historical or phonological grounds that suggest the phoneme $/ n /$ did not occur in coda position of the first syllable of the plural pronoun nandi. This phoneme is recorded in all known descriptions of the language undertaken in the last 150 years (not to mention reliable internal reconstructions of the personal pronouns). The question, therefore, is why the second phoneme $/ n /$ of this pronoun had no graphic representation in LG. A possible explanation lies in the quality of the vowel lal positioned between two identical nasals. At the level of the phonetic realization the vowel /a/ could have undergone nasal assimilation to the following $n$, the latter being phonetically (but not phonemically) lost: [nã $\mid d i]$. A similar phonetic change is observed in modern Yerwa Kanuri: /nandi $\rightarrow[$ anyi]). Yet it is still unclear why the nasality of the vowel /a/ was left graphically unmarked. Was [ã simply indistinguishable as an allophone of the phoneme /a/, or was it not transcribed because of deficiencies in the writing system itself?

\section{Interpretation of selected glosses from $1 Y M$}

It was noted in section IV that segmentation of a verb lexeme, always written as a single graphic word, is the most problematic element of LG decipherment. Here, some decoded morphemes of the verbal complex are discussed with examples of glosses from 1YM. I consider such morphological segments to be a primary tool for further analysis of LG. The description of the decoded glosses is given in Table 8 .

\section{The subject marker of the 2 nd person plural}

The gloss kirfandìyonh in R2 represents a class 1 verb form with the root fand 'find'. This verb is used here for translation of the Arabic verbal phrase haythu thaqiftumūhum (lit.: 'where you (pl. m.) found them'). The graphic segment -iyonh which follows the verb root fand is not explicit in its morphemic structure, though logically should comprise a subject morpheme marker. I assume that the SJ2PL marker is encoded by the second letter $y \vec{a}$, while the following graphic sequence ( $w \bar{a} w$ marked by damma, nūn and $h \vec{a}$ ) conveys a TAM marker $-n$ (modern imperfect marker) preceded by an epenthetic vowel $-o$-. The proposed reconstruction is based on Lukas' data on the Kaidi-Kanembu dialect:

$r u-y-o-n$

'see'-SJ2PL-EP-TAM 620-21).

${ }^{29}$ See Cyffer (1981: 186, 190); and also Nilo-Saharan reconstruction of ${ }^{*} \mathrm{~K}^{\mathrm{h}}$ in Ehret $(2001$ : 
Table 8. Glosses in 1YM

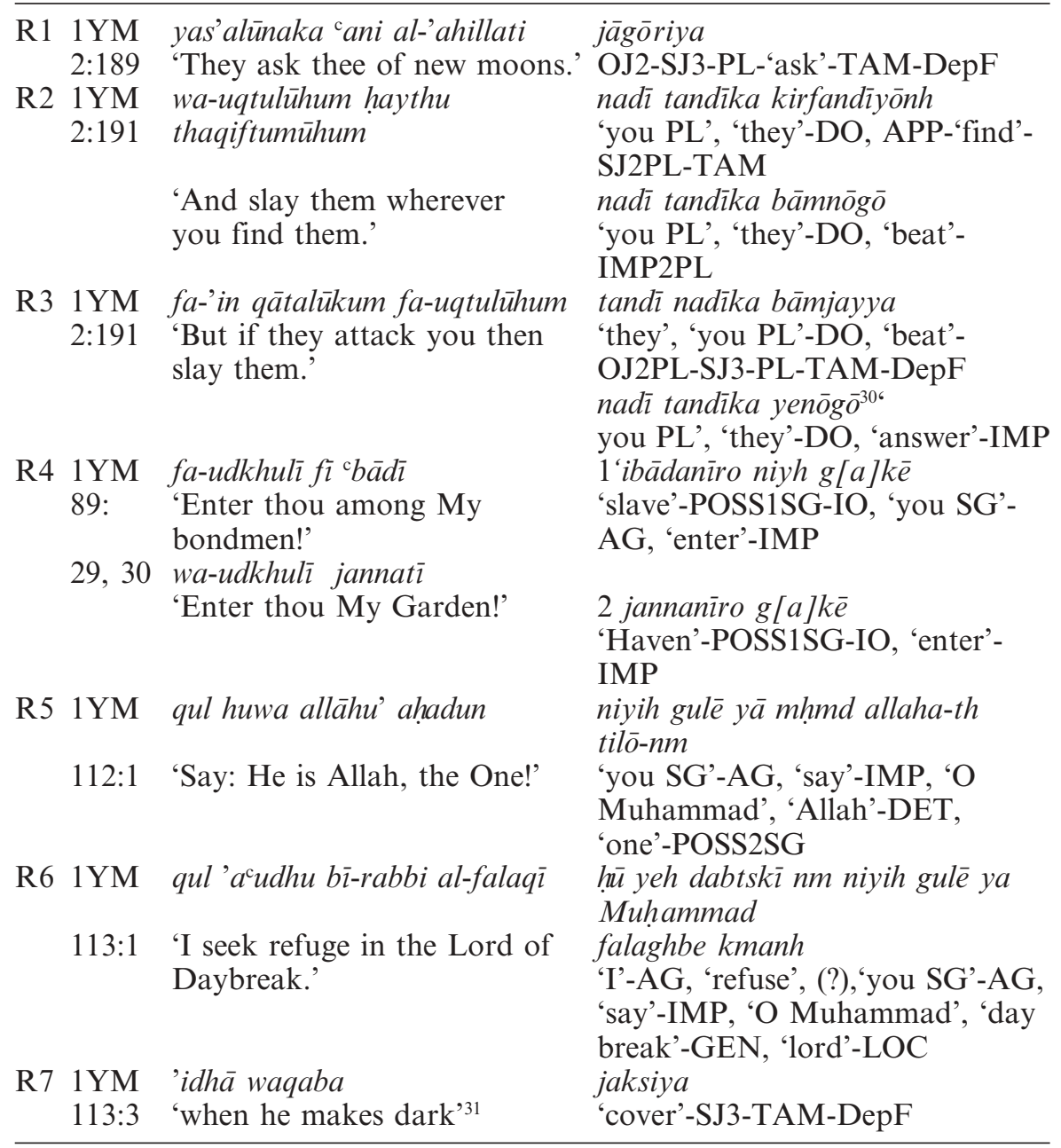

This form is inflected from the verb rukin 'see'32 (cf. the inflection of the same verb in the same grammatical category (imperfect) in Yerwa Kanuri, i.e. ruwin).

2. The subject marker of the 3rd person (sg./pl.) and object marker of the 2nd plural

The gloss bämjayya, 'if they beat (?)/kill (?) you' (class 2 verb) in R2 gives evidence of the phonetic realization of the 3rd person subject morpheme $s$ and the object morpheme $j / n j$, both encoded by the letter jim .

\footnotetext{
${ }^{30} \mathrm{My}$ text (here and henceforth) does not reproduce imāla-the dot below the letter $k \bar{a} f$ denoting the vowel $e$.

${ }^{31}$ My translation.

${ }^{32}$ Lukas (1931: 43).
} 
surface (written) form:

bämjayya

suggested underlying form:

bak-nz-s-a-i-ya

'beat'-OJ2PL-SJ3-PL-TAM-DepF

The merging of the object marker with the $3 \mathrm{rd}$ person subject morpheme is typical of modern Kanuri phonology. Comparison of the given gloss with two other glosses from 1YM helps verify this interpretation.

a) In the gloss jaksiya 'when he covers' (R7) we find the same subject morpheme $s$ within a class 2 verb structure (the verb zanggin 'close, cover' with the meaning-carrier zak in contemporary Yerwa). The exponent of this morpheme is the phoneme $s$ in the strong position (i.e. after the voiceless obstruent $k$ ).

surface (written) form:

jaksiya

suggested underlying form:

jak-s-i-ya

'cover'-SJ3-TAM-DepF

b) The gloss jāgōriya 'if they ask you' (R1) represents a class 1 verb with the prefixed object morpheme $j / n j$ merged with the prefixed subject morpheme (the verb is kórəkin 'ask', in Yerwa Kanuri).

surface (written) form:

jāgōriya

suggested underlying form:

$j-s-a-k o r-i-y a$

OJ2-SJ3-PL-'ask'-TAM-DepF

It is possible that the prenasalized form of the object morpheme was only realized in a class 2 verb where it occurred after the meaning-carrier morpheme at the syllable boundary (in case of the gloss bamjayya after bak: bak-nj > bamj).

There is, however, a slight possibility that the gloss bamjayya has no object marker at all, $j$ being only an exponent of the subject morpheme $s$ (cf. the correspondence $j: z$ in $j a k$ (LG) and $z a k$ (Kanuri)). But in this case it would be doubtful that the gloss bamjayya represents an inflection of the verb bánggin (MC bak) 'beat', because the realization $[\mathrm{mj}]$ at the morpheme boundaries between $/ k /$ and $/ s /$ is impossible (/bak-s/ $>*[$ bamj]).

\section{Imperative markers}

Two imperative morphemes were found in 1YM: 2nd sg. $-\bar{e}$ (modern Kanuri $-\dot{e}$ ) and 2nd pl. $-g \bar{o}$ (modern Kanuri -wó). The imperative marker for 1 st pl. (Kanuri -yówó) has not yet been observed in the manuscripts.

The 2 nd sg. imperative marker $-\bar{e}$ is represented in the glosses $g[a] k \bar{e}$ 'enter!' (R4) and gule 'say!' (R5, R6). This marker is in all cases identically represented by a fixed combination of signs: imāla (a diacritical sign denoting vowel $e$ ) and the letter $y \bar{a}$ ' with the slant alif above.

The 2nd pl. imperative marker $-g \bar{o}$ is observed in the glosses bāmnōgo 'beat/ kill!' (R2) and yenōgō 'answer!' (R3). The vowel $o$ is invariably represented by the sign damma and the wäw.

All these examples seem very promising for further reconstructions, as they show a spelling convention consistently applied to denote one grammatical 
category. If the writing system clearly marked one inflectional paradigm, then we may hope to find a uniform marking of other paradigms.

It is worth mentioning that the gloss $g[a] k \bar{e}$ 'enter!' shows the consonant $k$ as the onset of the second syllable. Because of a process of lenition this consonant has disappeared in the modern verb root gaá 'enter'.

\section{The dependent future morpheme}

The previously discussed glosses jāgōriya 'if they ask you' (R1), bāmjayya 'if they beat (?)/kill(?) you' (R3), and jaksiya 'when he covers' (R7) contain a morpheme $-y a$ (here called dependent future $(\mathrm{DepF})$ ), which signifies a conditional relation between the main and subordinate clauses. The DepF morpheme $-y a$ is present in modern Kanuri and is believed by many scholars to be a functional variant of a multifunctional associative (or referential) morpheme $-\mathrm{Ca}^{33}$ This referential morpheme is also considered to operate as a modern direct object (DO) marker $-g a .^{34}$

It appears that the material of LG, at least at this stage of the study, does not support this view. On comparison of the glosses jāgoriya and jaksiya with the glosses for the personal pronouns in direct object positions marked by DO $-k a$ (non-weakened form of modern DO $-g a$ ), it is evident that at the time of LG the DepF marker was clearly distinct from the DO marker. Cf.: jāgōri-ya, jaksi-ya vs. nadi-ka, tandi-ka (R2, R3). Accordingly, it is unlikely that $-y a$ and $-k a$ could be exponents of the same morpheme. Otherwise, from a phonological point of view, it is impossible to explain why the consonant $/ k /$ of the same morpheme was realized differently in identical environments, that is intervocalically after front $/ i /$ :

$$
\begin{aligned}
& k^{\prime} \rightarrow k / i \_a(\mathrm{cf} . \text { tandika) } \\
& \text { but } \\
& k(?){ }^{\prime} \rightarrow y / i \_a(\mathrm{cf} . \text { jaksiya) }
\end{aligned}
$$

Thus, it is reasonable to view $-y a$ and $-k a$ in LG as exponents of two different morphemes with two different meanings and consequently, the modern DepF marker $-y a$ and DO marker $-g a$ cannot be considered as functional variants of the same morpheme.

\section{An applicative morpheme}

The gloss kirfandīyōnh '[where] you (PL) find' (R2) has already been discussed with regard to the 2 nd person subject marker. This gloss probably gives evidence of an applicative prefix *kir-. The modern class 1 verb fandókin 'find, get' represented in the gloss, has no applied extension. If it had, the derivative prefix should have been realized as yir- (as is observed in other class 1 verbs, e.g. yir-wafîn < bafîn). It is possible that LG preserved this morpheme in the form in which it occurred before lenition $k>g>y$.

\section{Kanuri vs. Kanembu (further thoughts)}

It has been mentioned that LG was identified by Bivar (1960) as Kanembu:

The language of the commentaries [in $3 \mathrm{ImI}$ ] is recognised by learned authorities in Maiduguri to be the Kanembu dialect .... In the case of the

\footnotetext{
${ }^{33}$ The marker $-y a$ is differently referred to as 'Dependent future' (Cyffer 1998: 70), 'Emphasis Completive' (Hutchison 1981: 294-5), and 'Conditional Associative' (Jarrett 1980: 15).

${ }^{34}$ Cyffer (1998: 70); Hutchison (1981: 211-12).
} 
Geidam Kuran, the conclusion that the language is Kanembu has subsequently received the authoritative confirmation of Professor J. Lukas... [who] was able to show that the words tandiye, tandika and tandiru represent inflected forms of the third person plural pronoun, 'they', to be compared with the Kanuri Sandiye, Sandika, Sandiru. (Bivar 1960: 201).

Although I think that the problem of the dialectal affiliation of LG is still far from solved, I will suggest my preliminary views on this issue. Before that, however, it is important to separate two different meanings conveyed by the term Kanembu. The first relates to the cultural reality and historical tradition, while the second is linguistic.

As a cover term, Kanembu is understood among the Kanuri to denote both their ancestor language and the language of ulama (Islamic scholars), which is used for commentary on the Quran, ${ }^{35}$ and also 'official' formal speech (for example, a conversation between the Waziri and Sheikh of Bornu). ${ }^{36}$ Whatever these cultural and historical connotations mean, they should not be confused with the linguistic reality, which may be different, especially when the language has no common literary norm.

As a linguistic term, Kanembu is used to denote a group of eastern dialects (the Kanembu dialect cluster) within the same Kanuri language, and I will use the term in this purely linguistic sense.

With regard to Lukas' confirmation of the language as Kanembu on the basis of the personal pronouns, it was most likely formed on a cursory acquaintance with the document. The form of the personal pronoun (tandi vs. sandi) is not sufficient to identify a Kanuri dialect. The form tandi is observed not only in the Kanembu dialect cluster, but also in the Manga dialect belonging to the (western) Kanuri cluster and in the Suwurti dialect which represents the link between the Kanuri and Kanembu dialect clusters (Bulakarima 1997: 74).

Preliminary comparison of the phonological, morphological and lexical properties of LG with those observed in the dialects of both the Kanuri and Kanembu clusters provides evidence that LG is closer to the Kanuri than to the Kanembu cluster. For example, the LG consonants had not undergone the weakening process. Consonant lenition is more widespread in the Kanembu cluster than in the Kanuri cluster, a fact which in historical perspective brings the latter closer to LG than the former. The similarity between LG and Kanuri is quite conspicuous in the verb morphology, especially in the inflections of the Kanembu class 2 verbs, which lose the consonant exponents of the subject morphemes (see Table 9).

Table 9 .

\begin{tabular}{lllll}
\hline & \multicolumn{4}{c}{ Affixes } \\
\cline { 2 - 5 } & 1st sg. & 1st pl. & 2nd pl. & 3rd \\
\hline LG & sk & - & y & s \\
Kanuri & $\mathrm{k}$ & $\mathrm{y}$ & $\mathrm{w}$ & $\mathrm{s}$ \\
Kanembu & $\overline{\mathrm{i}}$ & $\mathrm{e}$ & $\mathrm{o}$ & $\mathrm{i}$ \\
\hline
\end{tabular}


Table 10 .

\begin{tabular}{llll}
\hline LG & Kanuri & Kanembu & meaning \\
\hline dibal & dival & dual & road \\
fato & fato & foto & house \\
gul & gul & nu & to say \\
kntagə & Kontagə & kendau & new moon \\
musko & musko & nduko & hand \\
\hline
\end{tabular}

Lexically too LG seems to be closer to the Kanuri cluster. Cf. the examples shown in Table 10 from LG, as compared to Kanuri and Kanembu, documented by Lukas $(1931,1937)$ in the 1930s.

At present it is not possible to reach more definitive conclusions as to whether LG is the ancestor of any particular dialect within the Kanuri cluster, or whether it represents an extinct dialect. The possibility that LG was a specific written form of Kanuri of supra-dialect status cannot be ruled out, and as such it could represent a quasi-literate form of the language, the use of which was limited to quranic commentaries. This suggestion can be backed up by various phenomena considered in this paper, in particular, occurrences of identical glosses in different manuscripts (sections V and VI) and the existence of a particular spelling norm (section IV). Obviously, some time would have been needed for such unification. Accordingly, LG could represent a form of language which is in fact older than the date on manuscript 3ImI (1669) suggests.

\section{ABBREVIATIONS}

AG: agentive; APP: applicative morpheme; ASSOC: associative marker; CAUS: causative morpheme; DepF: dependent future morpheme; DEM: demonstrative; DET: determinative marker; DO: direct object; EP: epenthetic vowel; f.: feminine; GEN: genitive marker; IMP: imperative; IMPERF: imperfect; IO: indirect object; ImI: the 'Imam Ibrahim Quran'; LG: the language of the glosses; LOC: locative; m.: masculine; MC: meaning-carrier morpheme; NA: noun agent; NEG: negative; OJ2: object marker of the 2nd person; POSS: possessive pronoun; PL, pl.: plural; SG, sg.: singular; ShK: the 'Shetima Kawo Quran'; SJ1/2/3: subject marker of the 1st, 2nd or 3rd persons; TAM: tense-aspect-mood marker; VN: verbal noun, YM: the 'Yerima Mustafa Quran'.

\section{REFERENCES}

Bivar, A.D.H. 1960. 'A dated Kuran from Bornu', Nigeria Magazine 65, 199-205.

Bivar, A.D.H. 1968. 'The Arabic calligraphy of West Africa', African Language Review 7, 7.

Bulakarima, Shetima Umara. 1997. 'Survey of Kanuri dialects', in N. Cyffer and T. Geider (eds), Advances in Kanuri Scholarship. Cologne: Rüdiger Köppe Verlag, 67-75.

Cyffer, Norbert. 1981. 'The person elements in Saharan languages', Nilo-Saharan: Proceedings of the first Nilo-Saharan Linguistic Colloquium. Dordrecht/Cinnaminson, 185-200.

Cyffer, Norbert. 1988-1989. 'Language change in a Nigerian language: Koelle's "African Native Literature" and present-day Kanuri', Harsunan Nijeria 14, 40.

Cyffer, Norbert. 1997. 'A survey of the Kanuri language', in N. Cyffer and T. Geider (eds), Advances in Kanuri Scholarship. Cologne: Rüdiger Köppe Verlag.

Cyffer, Norbert. 1998. A Sketch of Kanuri. Cologne: Rüdiger Köppe Verlag.

Cyffer, Norbert and Thomas Geider (eds). 1997. Advances in Kanuri Scholarship. Cologne: Rüdiger Köppe Verlag.

Cyffer, Norbert and John P. Hutchison. 1990. Dictionary of the Kanuri Language. (Publications in African Languages and Linguistics.) Dordrecht/Providance: Foris; University of Maiduguri. 
Déroche, François. 1985. Les Manuscrits du Coran. Du Maghreb à l'Insulinde. Paris: Bibliothèque nationale.

Dobronravin, Nikolai A. 1999. Arabograficheskaya pis'mennaya traditsiya Zapadnoy Afriki [Arabic-script written tradition of West Africa]. St. Petersburg: SPb University.

Ehret, Christopher. 2001. A Historical-Comparative Reconstruction of Nilo-Saharan. Cologne: Rüdiger Köppe Verlag.

Habraszewski, Tomasz. 1967. 'Kanuri-language and people - in the "Travel book" (Siyahetname) of Evliya Çelebi', Africana Bulletin 6, 59-66.

http://www.equran/org/qrn/view/mohsin/2.html (18.04.2004): Mohsin Khan and Muhammad Al-Hilali, Translation of Holy Quran.

http://www.intratext.com/ixt/ENG0027/_P3.htm (18.04.2004): Muslim Students Association of Oregon State University, The Holy Quran: Index.

Hutchison, John P. 1981. A Reference Grammar of the Kanuri Language. Madison: University of Wisconsin.

Ibn Juzayy, Muḥammad ibn Aḥmad. 198-?. al-Tashīl li-culūm al-tanzīl. [Libya]: al-Dār al-'ªrabīya lil-Kitāb.

Jarrett, Kevin A. 1978. 'Vowel length in Kanuri', Harsunan Nijeriya VIII, 21-49.

Jarrett, Kevin A. 1980. 'Tense/aspect/mood in Kanuri verb norms', Harsunan Nijeria X, 1-27.

Jouannet, Francis. 1982. Le kanembu des Ngaldoukou: Langue Saharienne Parlée sur les Rives Septentrionales du Lac Tchad. Phonématique et Prosodie. (Bibliotheque 91-92.) Paris: SELAF.

Koelle, Sigismund Wilhelm. 1854. African Native Literature, or Proverbs, Tales, Fables, and Historical Fragments in the Kanuri or Bornu Language. London: Church Missionary Society.

Lange, Dierk. 1972. 'Un vocabulaire kanuri de la fin du XVIIe siècle', Cahiers d'Etudes Africaines $12,278-90$.

Lukas, Johannes. 1931. Die Sprache der Káidi-Kanembú in Kanem. Berlin: Dietrich Reimer.

Lukas, Johannes. 1937. A Study of the Kanuri Language: Grammar and Vocabulary. London: Oxford University Press.

Pickthall, Muhammad Marmaduke. 1999. The Meaning of the Glorious Qur'an: Text and Explanatory Translations. Elmhurst: Tahrike Tarsile Qur'an. 